\title{
鉄軌道利便性および歩行者空間分布を考慮した 地方都市における都市構造の国際間比較
}

\author{
松中 亮治 1 - 大庭 哲治 $2 \cdot$ 中川 大 $^{3}$ - 長尾 基哉4 \\ 1正会員 京都大学大学院准教授 工学研究科都市社会工学専攻（ $=615-8540$ 京都市西京区京都大学桂） \\ E-mail:matsu@urban.kuciv.kyoto-u.ac.jp \\ 2正会員 京都大学大学院助教 工学研究科都市社会工学専攻（干615-8540 京都市西京区京都大学桂） \\ E-mail: tetsu@urban.kuciv.kyoto-u.ac.jp \\ 3 正会員 京都大学大学院教授 工学研究科都市社会工学専攻（ $=615-8540$ 京都市西京区京都大学桂） \\ E-mail: nakagawa@urban.kuciv.kyoto-u.ac.jp \\ 4 正会員 四国旅客鉄道株式会社（†760-8580 香川県高松市浜ノ町 8-33）
}

\begin{abstract}
本研究では, 日本・フランス・ドイツの全地方都市を対象として, 鉄軌道駅の運行頻度ならびに歩行者 空間の分布状況と都市構造との関連を実証データにより国際間で比較した。その結果，ドイツにおいて都 市全体の人口に占める駅周辺人口の割合が日本やフランスに比べて高い都市が多く存在し，ドイツ，フラ ンス，日本の順で，鉄軌道駅と歩行者空間との近接性が高いことを実証的に明らかにした．さらに，総合 的な都市構造指標を主成分分析により導出し, 都市構造のコンパクト性を比較した結果, ドイツの都市構 造は，日本やフランスの都市に比べてコンパクトであること，また，日本とフランスの都市を比較すると， 歩行者空間と鉄軌道駅との近接性の差を考慮した場合，フランスの都市の方がコンパクトであることを定 量的に明らかにした。
\end{abstract}

Key Words : urban structure, service frequency, distribution of population, pedestrian spaces

\section{1. はじめに}

近年注目されているコンパクトシティ構想では, 利便 性の高い公共交通や都心部の賑わいをもたらす歩行者空 間整備の重要性が指摘されている1)ものの，わが国の特 に地方都市においては，実際に利便性の高い公共交通や 都心部の賑わいをもたらす歩行者空間の整備が進んでい るとは言い難い状況である．また，一般に，わが国の都 市と比較して，地方都市においても，ヨーロッパの都市 はコンパクトな都市構造を維持している゙2と言われてい るが，ヨーロッパの都市がわが国の都市と比較してどの 程度, そして, どういったコンパクトな都市構造を有し ているかについては，これまで十分に定量的な比較分析 が行われているとは言えない。

コンパクトシティとは, 居住や業務などの都市活動の 空間的密度が高い地域であり，通常，都市活動密度の高 い中心核や鉄道等交通軸沿道地域（コリドール）を有す る地域という『形態』面での特徴も含意して使用されて いる場合が多く3)，また，コンパクト化を考える際の分 析視座として, 環境負荷抑制や都市経営の効率化と共に,
モビリティの確保が挙げられている4゙.

実際の都市構造は個々の事業や都市整備および諸規制 などの積み重ねによって体現されるものであり，コンパ クト化政策を推進する際にも，都市全体を対象とした分 析では不十分であり, 実際の事業に対応した町丁目など の地区レベルでの情報が求められている5゙,6.

従って, 都市のコンパクト性を国際間比較する場合, 単に, 都市全体の人口や人口密度を用いて比較するだけ では十分であるとは言えず，単に人口が集中しているだ けでなく，そこに利便性の高い公共交通サービスが提供 されているか，都心部に賑わいをもたらす快適な歩行空 間が確保されているかといった点についても考慮した上 で, 都市内人口の空間分布を比較する必要がある.

Newman and Kenwarthy”に代表されるような都市のコン パクト性と交通エネルギー消費の関係性を示した研究は これまでにも多く蓄積されているが9,9,10)，これらの研究 では, 都市のコンパクト性が都市人口密度といった都市 全体の指標で捉えられている. これらの研究に対し，近 年では, 都市内の地区レベルで都市のコンパクト性を把 握した研究も数多くみられるようになっており 5, 0,11,12), 
本研究と同様に，都市内交通の利便性を鉄軌道の運行頻 度を用いて把握した上で，駅周辺の人口分布との関連性 を詳細に分析し，都市内交通の利便性と都市構造の関連 性を明らかにした研究13),14)もある.しかしながら，これ らの研究はいずれも, 都市のコンパクト性を国際間で比 較分析し，その特徵を明らかにしたものではない.

一方，都市内交通の整備状況と都市特性の関係を国際 間で比較した研究として, Hass-Klau and Crampton ${ }^{15)} の$ 研 究が挙げられる.この研究では，ピーク時の運行頻度な どの都市や沿線の特性を用いて, LRT 導入の成功要因 が分析されているが，分析対象がヨーロッパ・北米諸国 の 24 都市に限定されており，また，LRT 以外の鉄軌道 交通機関についても考慮されていない. その他にも，わ が国とフランスの二国間で, 路面電車運行都市を対象と して, 都市および沿線特性を比較分析した松中ら ${ }^{16)}$ の研 究や，対象を国内に限定すると，路面電車等の整備状況 と自動車利用量の関係を全国レベルで明らかにした中道 ら ${ }^{17} の$ 研究があるが，いずれも鉄軌道の運行頻度といっ た都市交通の利便性までは十分に考慮されてはいない.

また，都市内の歩行者空間と都市構造との関連につい ては，歩行者空間沿道の商店主に歩行者空間の設置前後 の売り上げの変化を尋ねることにより，歩行者空間設置 が周辺の商業活動に与えた影響を明らかにしたもの ${ }^{18) や ~}$ 歩行者空間の整備状況と商店街の賑わいの関連性を分析 したもの ${ }^{19)}$ ，歩行者空間とのアクセス性やエネルギー消 費の観点から，LRT などの公共交通機関別に都市構造 への影響を考察したもの ${ }^{20)}$ がみられる程度であり，十分 な研究蓄積があるとは言えない.

以上のように，既往研究では，一定の基準を満たす都 市を網羅的に全て抽出し，かつ市町村より細かい地区レ ベルで，鉄軌道利便性や歩行者空間の分布状況と都市構 造との関連を分析し，都市のコンパクト性を国際間で比 較した研究はみられない.

そこで本研究は，日本とヨーロッパ諸国の地方都市に おける，鉄軌道駅の運行頻度ならびに歩行者空間の分布 状況と都市構造との関連を実証データにより国際間比較 し，都市構造の差異を定量的に明らかにすることを目的 とする. 具体的には，日本，フランス，ドイツの全地方 都市を対象として，「鉄軌道駅周辺の人口分布」，「人 口密度の高い地区の分布」，「都市中心部の歩行者空間 の分布」の3つの観点で都市構造をとらえ，鉄軌道駅の 運行頻度と都市構造との関連を分析する. そして, これ ら 3つの観点より得られた都市構造を表す指標から総合 的な都市構造指標を提案し, 都市構造のコンパクト性を 国際間比較する．なお，本研究では，各交通手段の輸送 量やデータの制約・収集可能性を考慮し, 都市内交通機 関として鉄軌道を対象とすることとした。

\section{2. データベースの構築}

\section{（1）対象都市および対象鉄軌道駅の定義}

本研究では，公共交通を活用し，比較的コンパクトな 都市構造を維持しているといわれるヨーロッパ諸国のう ち，近年，急速に都市内公共交通ネットワークの整備を 進めているフランス，古くからの都市内公共交通ネット ワークを維持し続けているドイツの 2 力国を取り上げ, 公共交通体系が機能すると考えられる 10 万人以上の都 市人口を有しており，大都市圏に含まれず，かつ都市内 に鉄軌道駅を有する全ての地方都市を分析対象とする. 日本については，鉄道事業法に基づいて敷設された路線 にある駅を「鉄道駅」と定義し，軌道法に基づいて敷設 された路線にある駅を「軌道駅」と定義する．鉄道駅と 軌道駅の両方に該当する駅については全て鉄道駅として 扱う。フランス，ドイツについては，各運行事業者のウ ェブサイト上での扱いに従う。フランスについては,

「Métro」と明記されるか，系統番号が「M」から始ま る路線は「地下鉄」に分類し，「Tram」と明記される か, 系統番号が「T」から始まる路線は「路面電車」に 分類し，フランス国有鉄道が運行する路線は「一般鉄 道」に分類する. ドイツについては，「U-bahn」と明記 されるか, 系統番号が「U」から始まる路線は「地下 鉄」に分類し，「Straßenbahn」，「Tram」と明記された 路線は「路面電車」に分類し，ドイツ鉄道株式会社が運 行する路線及び「S-bahn」と称される郊外鉄道は「一般 鉄道」に分類する. その上で，「一般鉄道」及び「地下 鉄」に分類される駅を鉄道駅とし，「路面電車」及びい ずれにも含まれないモノレールやラック式鉄道路線に分 類される駅を軌道駅と定義する. また，本研究で使用し た鉄軌道駅の位置データは次のとおりである。日本につ いては，国土数值情報 ${ }^{21)}$ に基づく 2005 年の鉄軌道駅の 位置データを使用した. フランス, ドイツについては, ESRI 社が提供する鉄道駅の位置データ22)を使用した。

なお，上記データに掲載されていない新駅などについ ては Google Map ${ }^{23)}$ 用いて位置座標を取得した．各国に おける対象都市ならびに鉄軌道駅の定義は以下の通りで ある。

\section{a) 日本}

2005 年に実施された国勢調査の結果を基に，人口 10 万人以上の都市を抽出し, これらの中から三大都市圈に 含まれる都市および 2005 年 10 月時点で鉄軌道駅が存在 しない都市を除いた，134 都市を対象とする．ここで， 三大都市圏に含まれる都市とは，首都圏整備法における 既成市街地および近郊整備地帯，近畿圏整備法における 既成都市区域および近郊整備区域，中部圈開発整備法に おける都市整備区域を有する都市とする. 対象とする鉄 軌道駅は，2005 年 10 月時点で対象都市内に存在する 
表-1 運行頻度別鉄軌道駅数

\begin{tabular}{c|r|r|r|r|r|r}
\hline 運行頻度 & \multicolumn{2}{|c|}{ 日本 } & \multicolumn{2}{c|}{ フランス } & \multicolumn{2}{|c}{ ドイツ } \\
\cline { 2 - 7 }$($ 本/h $)$ & 鉄道駅 & 軌道駅 & 鉄道駅 & 軌道駅 & 鉄道駅 & 軌道駅 \\
\hline$\sim 1$ & 342 & 0 & 292 & 2 & 30 & 1 \\
$1 \sim 2$ & 568 & 0 & 132 & 0 & 172 & 5 \\
$2 \sim 3$ & 384 & 11 & 25 & 1 & 175 & 11 \\
$3 \sim 4$ & 131 & 7 & 16 & 0 & 194 & 142 \\
$4 \sim 6$ & 226 & 32 & 6 & 47 & 125 & 314 \\
$6 \sim 12$ & 228 & 179 & 18 & 335 & 532 & 2,082 \\
$12 \sim$ & 24 & 206 & 138 & 226 & 325 & 1,036 \\
\hline 全体 & 1,903 & 435 & 627 & 611 & 1,553 & 3,591 \\
\hline
\end{tabular}

表-2 小地域データの概要

\begin{tabular}{|c|c|c|c|c|}
\hline 対象国名 & 小地域名 & $\begin{array}{c}\text { 人口 } \\
\text { データ }\end{array}$ & $\begin{array}{c}\text { 境界 } \\
\text { データ }\end{array}$ & その他 \\
\hline \multirow{2}{*}{ 日本 } & $\begin{array}{c}\text { 町丁目 } \\
\text { 3次メッジ }\end{array}$ & $\begin{array}{l}0 \\
0\end{array}$ & 0 & 約1 $\mathrm{km}$ 四方 \\
\hline & 4次メッシュ & 0 & 0 & 約500m四方 \\
\hline \multirow{2}{*}{ フランス } & IRIS & 0 & 0 & \\
\hline & ÎLOTS & 0 & $\Delta$ & \\
\hline \multirow{3}{*}{ ドイツ } & Postleitzahl & O & $\mathrm{O}$ & 区画面積が大きい \\
\hline & Statistische Bezirk & $\Delta$ & $\Delta$ & 主要都市内に限定 \\
\hline & Wohnquartier & 0 & 0 & \\
\hline
\end{tabular}

$\mathrm{O}$ : 利用可能 $\Delta:$ : 部地域のみ利用可能

: 本研究で用いた小地域データ

\section{2,338の鉄軌道駅とした.}

\section{b) フランス}

日本の市町村に相当するフランスのコミューンは，日 本やドイツにおける市町村と比べて小規模であり，また， 都市内交通についても, 通常, 複数のコミューンが一体 となって運営されている，そのため, 複数のコミューン によって構成される都市圈単位で分析寸る必要がある. そこで，2006 年に実施された国勢調査の結果を基に， 人口 10 万人以上の都市圈を抽出し，これらの中から首 都圈にあたるイル・ド・フランス地域圈のパリ都市圈お よび海外地域圈に位置寸る都市圈を除いた 52 都市圈を 対象とする. 対象とする鉄軌道駅は, 2006 年末時点で 対象都市内に存在する 1,238 の鉄軌道駅とした.

\section{c) ドイツ}

日本の「市」が郡に属さず「町村」よりも大きな行政 権限を有することを踏まえて, 対象都市の定義を決定し た. ドイツでは，小規模な自治体は郡に所属しているが, 規模の大きな自治体は郡から独立し，郡レベルの行政権 限を有寸る独立市(Kreisfreie Stadt)となっている.また, Hannover は周辺市町村と都市連合を結成し，独立市並み の行政権限を有する. さらに, Berlin, Hamburg, Bremen, Bremerhaven については郡よりも上位の州レベルでの行 政権限を有する特別市(Stadtstaat)である，そこで，2008 年 12 月 31 日時点の住民登録人口を基に，人口 10 万人 以上の独立市・都市連合および特別市を抽出し，これら の中から首都のベルリンを除いた，70 都市を対象とす る. 対象とする鉄軌道駅は，2008 末時点で対象都市内 に存在する 5,144の鉄軌道駅とした.

\section{（2）運行頻度の算出方法}

本研究では，鉄道・軌道の利便性を表す指標として， 各鉄道・軌道駅のオフピーク時における運行頻度を用い る.これは，ピーク時に比べて，等間隔のダイヤが設定 されて運行頻度の時間変動が小さい場合が多く, 鉄道・ 軌道の利便性をより適切に表すことができると考えられ るためである。

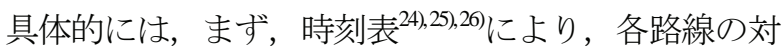
象駅について，オフピーク時に発車する列車を上り・下 りそれぞれの方向で計測し，その平均を取ることで各路 線での運行本数を算出寸る. 次に, 複数の路線が乗り入 れている駅については, 各路線での運行本数を足し合わ せて, 駅全体での運行本数を算出寸る. そして, 運行本 数をオフピーク時の時間数で除して運行頻度（本h）を 算出する. なお，オフピーク時は， 9:00〜16:59の8 時間とし, 運行頻度の算出にあたっては平日のダイヤを 用いる. 運行本数は, 寝台急行, 寝台特急, 臨時列車お よび運行日が月曜日から金曜日のうち 3 日未満に限定さ れる列車を除く全ての列車について計測する.

運行頻度データを基に，鉄道・軌道駅を運行頻度の高 低に応じて 7 つの運行頻度区分に分類する. 7 つの運行 頻度区分と, 運行頻度別の対象地方都市内の鉄道 - 軌道 駅数を，表-1に示寸.

\section{（3） 小地域人ロデータの詳細}

本研究では, 対象都市全域で市町村よりも詳細な地区 レベル（以降，小地域と呼ぶ）での人口データを GISに 実装することによって，比較分析を行うためのデータベ 一スを構築する. 分析に用いる小地域は, 人口データと GIS で利用できる境界データの両方を対象都市全域で入 手できる最小の小地域区画とした．市町村レベルよりも 詳細な小地域区画の一覧を表-2 に示す，以下に，本研 究で用いた小地域データの概要を示す.

\section{a) 日本}

日本の小地域データは, メッシュ単位のデータと町丁 目単位のデータに大別される. 町丁目単位のデータは, 特に郊外部で 1 区画の面積が大きくなる傾向にあり, メ ッシュ単位のデータよりも精度が低下寸ると考えられる ため, 本研究ではメッシュ単位のデータを用いることと する.メッシュ単位のデータには約 $1 \mathrm{~km}$ 四方の 3 次メ ッシュデータと約 500m 四方の 4 次メッシュデータがあ るが，本研究ではより詳細な人口分布を把握できる 4 次 メッシュデータを使用する，なお，人口データは，最新 の国勢調査メッシュデータである 2005 年のもの 27 を用 いることとした.

\section{b) フランス}

日本の市町村に相当する区画は Commune（コミュー ン）である。コミューンよりも詳細な小地域データとし 


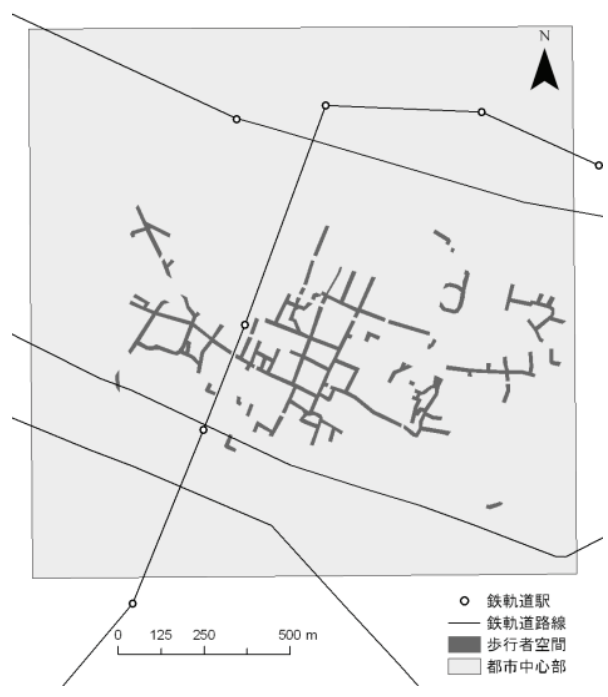

図-1＼cjkstart歩行者空間データの例（フランス・Rouen）

ては，国勢調査時に設定される IRIS(Illots regroupés pour linformation statistique)と ÎLOTS が挙げられる. IRIS は 1 区 画あたりの人口がおおむね 5,000 人未満になるように区 画が設定されており， ILOTS は IRIS をさらに細分化し た区画である，本研究では，境界データを概ね対象都市 全域で入手可能な IRIS 単位のデータを小地域人口デー タとして用いることとする，なお，人口データは，最新 の国勢調査データである 2006 年のもの ${ }^{28)}$ を用いること とした.

c) ドイツ

日本の市町村に相当する区画はGemeindeである. Gemeindeよりも詳細な小地域データとしては，区画面積 の大きい順に，Postleitzahl（郵便番号区分），Statistische Bezirk（統計地区），Wohnquartier（住宅地区）が挙げら れる. Postleitzahlは1区画あたりの面積が大きいため, Statistische Bezirkは主要都市内のみに限定されるため, 本 研究ではWohnquartier単位のデータを小地域人口データ として用いることとする，なお，人口データは，最新の 区画データと同じ2008年のもの ${ }^{29}$ を用いることとした.

\section{（4）歩行者空間のデータ}

歩行者空間のデータは，地下鉄・路面電車およびモノ レール等（以下，軌道系都市内交通と記寸）を有する都 市を対象に，都市地図およびGISを用いて作成した．対 象都市数は，それぞれ，日本 19 都市，フランス 18 都市， ドイツ46都市である.

歩行者空間のデータは，まず，市販の都市地図 ${ }^{30,311,32) ~}$ に都市中心部として拡大表記されている範囲（以下，都 市中心部と記す）をスキャンし，GIS 上で位置座標を与 え, 次に, 「車両通行禁止」・「アーケード」・

$\lceil$ Pedestrian street $\rfloor$ • $\lceil$ Pedestrian zone $\rfloor$ • $\lceil$ Pedestrianized
Road」の凡例で表される区域をポリゴン化することによ り作成した．作成した歩行者空間データの例を図-1に 示す，なお，本研究では，地表上にあり，かつ，自動車 の進入が禁止された道路空間を歩行者空間として扱って いるが，これは，それぞれの都市の都市中心部において， 限りある都市空間の中で，人々の移動のために配分され ている道路空間のうち，最も貴重な地表上の空間がどれ だけ歩行者に配分されているかに着目しているためであ る.したがって，地下街やペデストリアンデッキ，公園 等は本研究における歩行者空間には含まれない点に留意 する必要がある．また，公園内の園路は，公園の効用を 全うするために設けられる施設であるため，本研究にお ける歩行者空間には含めないこととした.

なお，都市中心部については，各都市において明確に 定義されていないため, 上述の方法で定義しているが, それぞれの都市中心部を確認した結果，いずれも都心部 分を含む $120 〜 1,500 \mathrm{ha}$ の範囲となっており，この範囲を 本研究では都市中心部として用いることとした.

\section{3. 鉄軌道駅周辺の人口分布と鉄軌道駅の運行頻 度との関連分析}

\section{（1）鉄軌道駅周辺への人口集中度}

$500 \mathrm{~m}$ 駅勢圈域内の人口が都市人口に占める割合（以 下，駅勢圈域人口割合と記す）および便利な駅（運行頻 度が高い駅として，3 本 $\mathrm{h}$ 以上の鉄道駅および 6 本 $\mathrm{h}$ 以 上の軌道駅を合わせたもの）の駅勢圈域人口割合を算出 した．ただし，500m 駅勢圈内の人口は GIS を用いて面 積按分法を用いて算出している. 各都市の駅勢圈域人口 割合および便利な駅の駅勢圈域人口割合を，日本につい ては図-2に，フランスは図-3に，ドイツは図-4にそれ ぞれ示す，なお，図-2～図-4においては，各国の都市を 都市人口が多い順に並べて示している.

各国で最も駅勢圈域人口割合が高い都市は，日本は広 島市(34.3\%)，フランスは Grenoble(43.0\%)，ドイツは Karlsruhe(74.0\%)である。軌道系都市内交通の有無に着目 すると，フランスやドイツでは軌道系都市内交通のない ほとんどの都市で駅勢圈域人口割合が 15\%を下回るが, 日本では高松市のように，軌道系都市内交通が存在して いない都市でも駅勢圈域人口割合が 30\%以上と比較的高 い都市が存在している。このような都市では，鉄道の一 部（高松市の場合，高松琴平電気鉄道の路線）が軌道系 都市内交通に近い役目を果たしているものと考えられる. また, 各国の都市全体の駅勢圈域人口割合は, 日本 15.6\%, フランス, $18.5 \%$, ドイツ 43.7\%となり, 特に, 駅勢圈域人口割合が $40 \%$ 上回る都市は，日本には 1 都 市も存在しないのに対し，フランスでは Grenoble, 


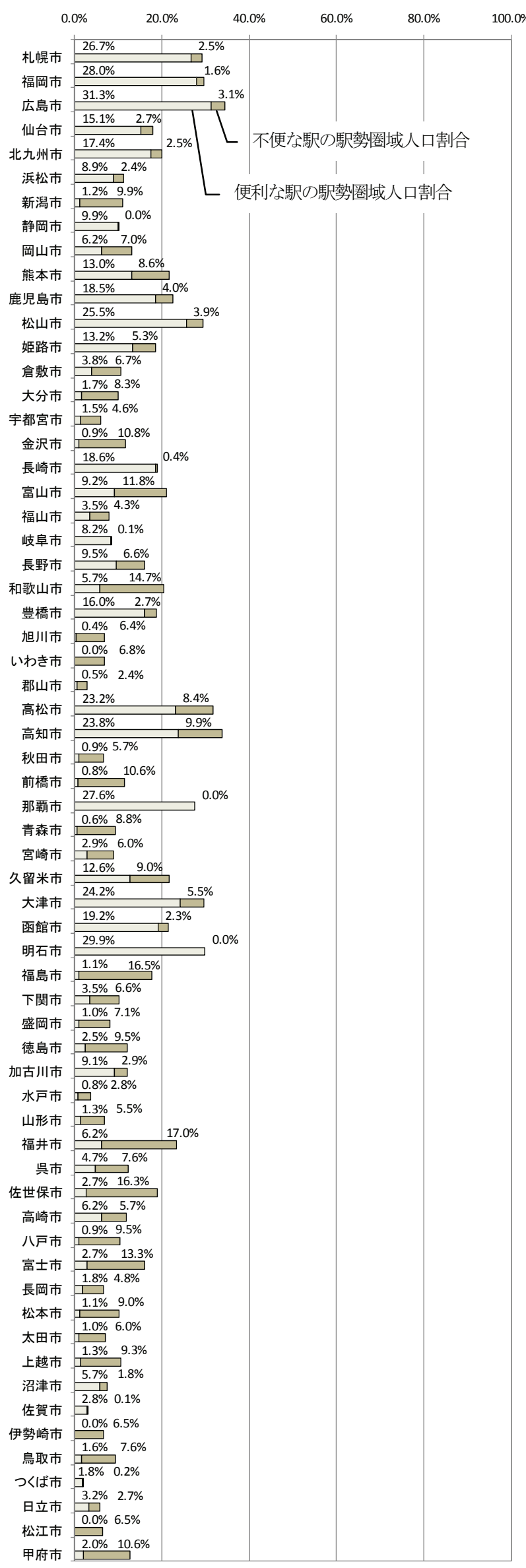

図-2(1) 各都市の駅勢圈域人口割合（日本）

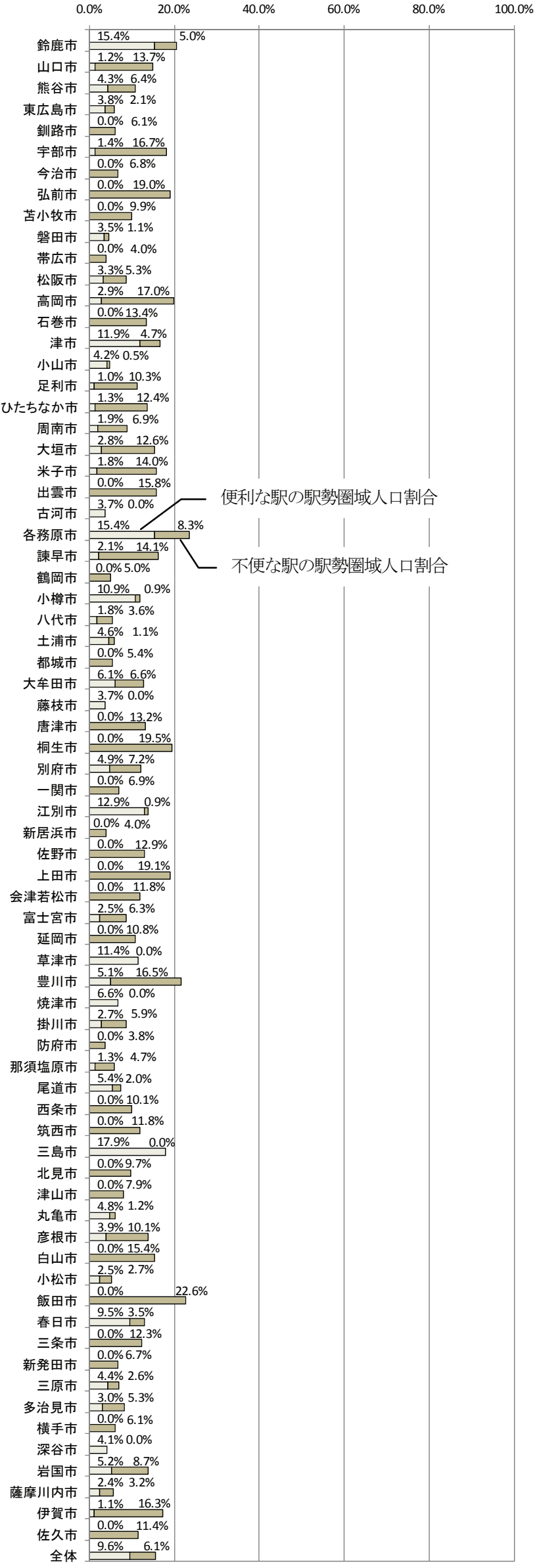

図-2(2) 各都市の駅勢圈域人口割合（日本） 


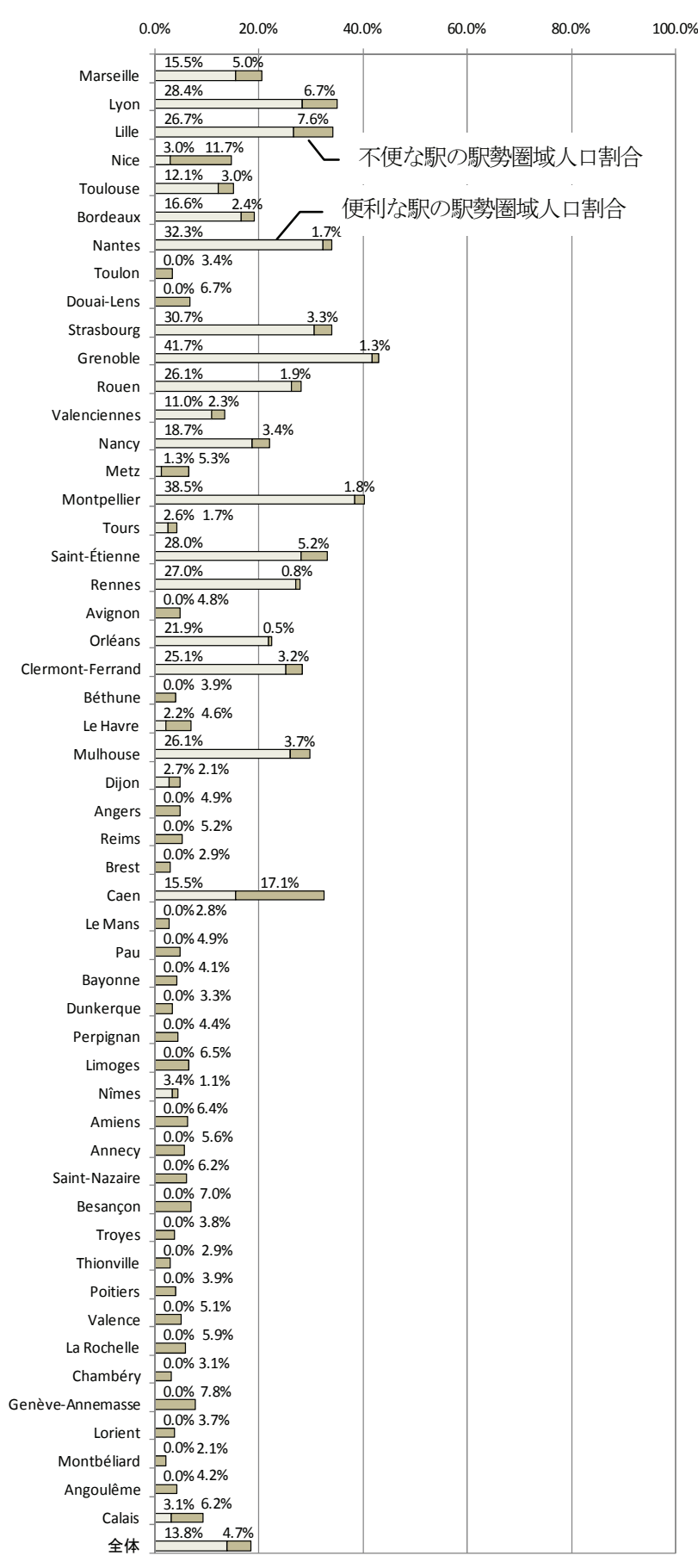

図-3 各都市の駅勢圏域人口割合（フランス）

Montpellier の 2 都市，ドイツでは Karlsruhe の 74.0\%を筆 頭に 37 都市存在し，各国間の相違が顕著に現れる結果 となった.

さらに，日本およびフランスにおいては，比較的都市 人口の少ない都市で，便利な駅の駅勢圏域人口割合が低 くなっているのに対して, ドイツでは, Jenaや Cottbus, Gera など人口の少ない都市においても，便利な駅の駅勢 圈域人口割合の高い都市が多く見られるのも特徵的であ る.これは，ドイツでは古くから軌道系都市内交通ネッ

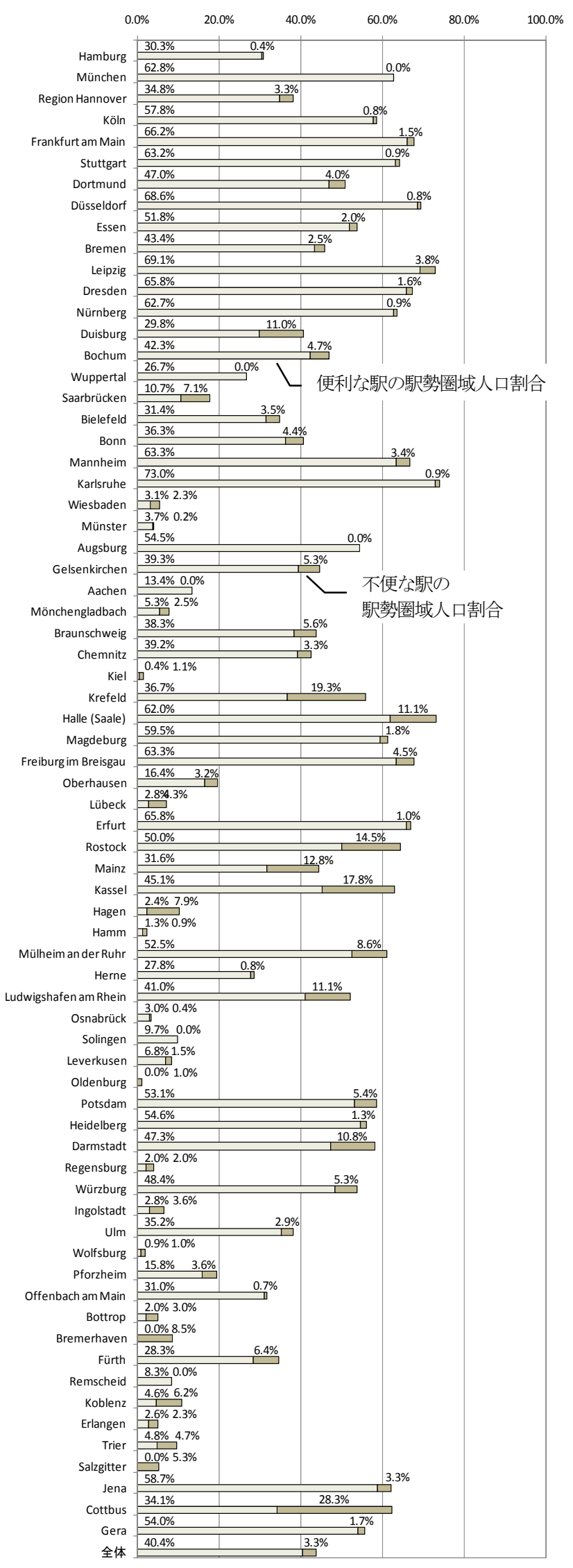

図-4 各都市の駅勢圈域人口割合（ドイツ） 
トワークが都心部で密に構築されている都市が多く, ま た，駅勢圈域が広い上に，郊外の集落にも軌道系都市内 交通が到達するようネットワークが構築されているため, 駅勢圈域人口割合が高いコンパクトな都市が多くなった ものと考えられる.

\section{（2）鉄軌道駅と人口密度の高い地区の近接性}

本節では, 人口密度 40 人/ha 以上の地区（以下，高密 地区と記す）および人口密度 100 人ha 以上の地区（以 下，超高密地区と記す）に着目して，運行頻度の高い鉄 軌道駅との近接性を分析する.

まず，都市人口に占める高密地区人口および超高密地 区人口の割合（高密地区人口割合・超高密地区人口割 合）を算出した。一例として，都市人口がいずれも 30 万人前後の函館市（日本），Saint-Étienne（フランス）お よび Mannheim（ドイツ）を例として，超高密地区およ び高密地区と鉄軌道駅の空間的な分布状況を図-5～図-7 に示す.

次に，対象都市ごとに高密地区および超高密地区の人 口に占める，便利な駅の駅勢圈域内の人口，不便な駅の 駅勢圈域内の人口および駅勢圈域外の人口のシェアを算 出した. 高密地区人口に占める, 便利な駅の駅勢圈域内 の人口, 不便な駅の駅勢圈域内の人口および駅勢圈域外 の人口のシェアを国単位で集計したものを，図-8に示 す.

全対象都市での高密地区人口に占める便利な駅の駅勢 圈域内の人口シェアは, 高い順にドイツ $55.6 \%$, フラン ス 24.9\%，日本 $15.0 \%$ となっおり，ドイツの都市では, 他の 2 国と比較して人口密度の高い地区と運行頻度の高 い便利な駅との近接性が高く, コンパクトな都市構造の 実現に寄与していると考えられる，逆に，日本では，高 密地区の $78.9 \%$ も人々が鉄軌道駅から $500 \mathrm{~m}$ 以上離れ た場所に居住しており, 都市内交通の利便性が高い地区 に必ずしも高密に人々が居住しているとは限らないこと を示している.

高密地区人口に占める便利な駅の駅勢圈域内の人口シ エアは，軌道系都市内交通のある都市の割合が高い国ほ ど高くなっているが，フランスと日本との間の差はドイ ツとフランスとの間の差に比べて小さくなっている.こ れは, 日本では, 軌道系都市内交通のない都市において も運行頻度が高く駅間距離の短い鉄道が運行されている 場合があり，そのような鉄道が軌道系都市内交通に近い 役割を担って高密地区人口に占める便利な駅の駅勢圈域 内の人口シェアを高めているためと考えられる.

さらに, 高密地区人口に占める便利な駅の駅勢圈域内 の人口のシェアを都市別にみると, 日本では人口シェア が 40\%を越える都市は見られなかったが，フランスでは Nantes, Grenoble, Montpellier, Mulhouseの4都市, ドイツ

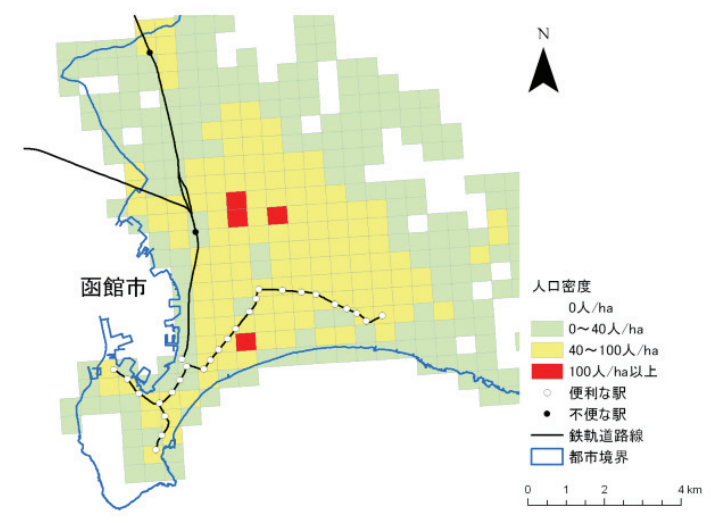

図-5 高密地区・超高密地区と鉄軌道駅の分布 (函館市)

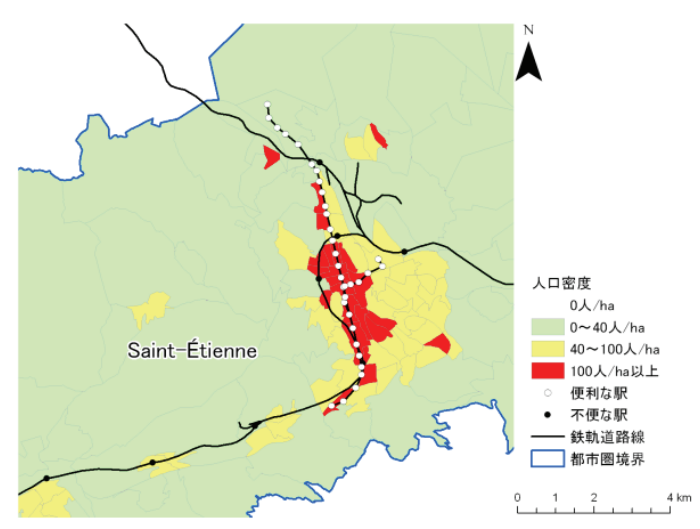

図-6 高密地区・超高密地区と鉄軌道駅の分布 (Saint-Étienne)

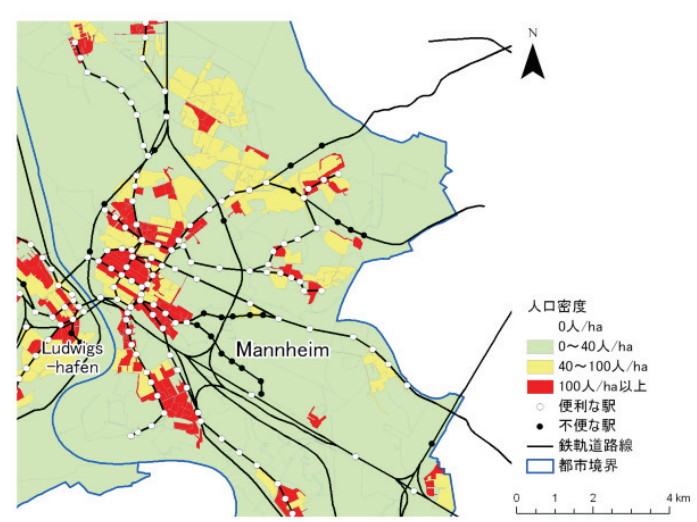

図-7 高密地区・超高密地区と鉄軌道駅の分布 (Mannheim)

では Karlsnuhe の 92.2\%を筆頭に 38 都市で 50\%を上回り， 特に，ドイツの各都市において人口密度の高い地区と鉄 軌道駅の近接性が高くなっている.

\section{4. 歩行者空間の分布と鉄軌道駅の運行頻度との 関連分析}

本研究の背景でも述べたように，コンパクトシティと は，通常，都市活動の空間的密度が高く，中心核や鉄道 


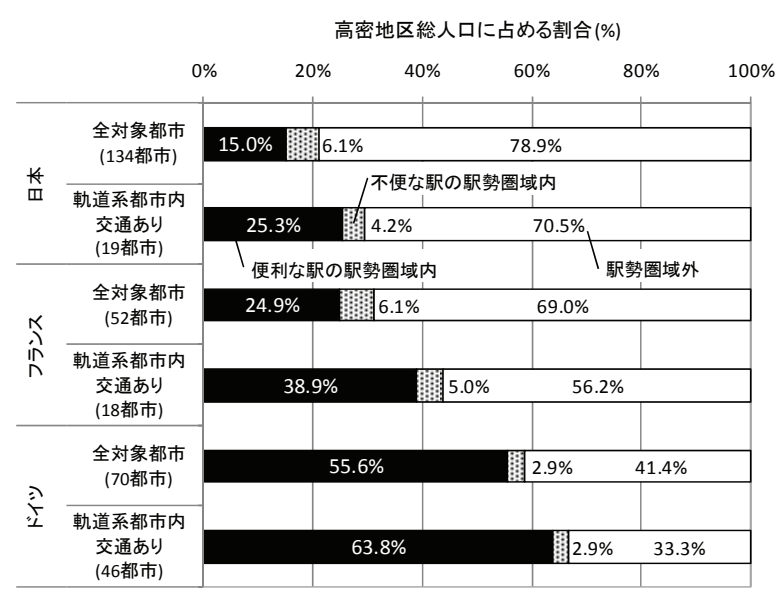

図-8高密地区内の人口シェア

等の交通軸沿道地域を有する地域 ${ }^{3)}$ とれている。 また， 自動車に依存しなくても日常生活に必要な都市機能が整 った徒歩圈と一定以上のサービス水準が確保された公共 交通からなるコンパクトな都市構造の形成を政策目標と して設定している都市もあり，コンパクトシティにおい ては利便性の高い公共交通や都心部の賑わいをもたらす 歩行者空間整備の重要性が指摘されている ${ }^{1)}$. さらに, 歩行者空間は，単に整備されるだけでは十分にその機能 を発揮できず，コンパクトな都市構造の骨格を形成する 公共交通施設との近接性・連続性が重要となる.

そこで，歩行者空間を都心部の中心核を構成する重要 な要素と考え，本章では，「都市中心部の歩行者空間の 分布」の観点から都市構造を捉え, 軌道系都市内交通の ある都市に関して，鉄軌道駅の運行頻度と都市構造との 関係，すなわち，利便性の高い鉄軌道駅と歩行者空間と の近接性について分析する.

まず，都市別の都市中心部 1ha あたりの歩行者空間面 積を GIS を用いて計測した結果を図-9に示寸．国別平均 の都市中心部 1ha あたりの歩行者空間面積は，都市中心 部が設定されていない都市（Valenciennes（フランス）お よび Heme, Fürth（ドイツ））を除くと，日本 $21.1 \mathrm{~m}^{2}$ ，フ ランス $191.7 \mathrm{~m}^{2}$ ，ドイツ $186.2 \mathrm{~m}^{2}$ となっており，日本の都 市中心部には，歩行者空間が少なく，フランスおよびド イツと比べると 9 分の 1 程度にとどまっている.

このように，日本の都市中心部は，フランス・ドイツ の都市と比較するとトランジットモールを含む歩行者空 間の整備状況に大きな差がみられるが，前述のように, 整備状況だけでなく, 歩行者空間がその機能を十分発揮 するために必要となる公共交通施設等との近接性を把握 することは, 都市構造のコンパクト性を比較する上で非 常に重要であると考える，そこで，ここでは，都心部の 中心核を構成する重要な要素と考えられる歩行者空間と 利便性の高い鉄軌道駅との近接性を明らかにするために,

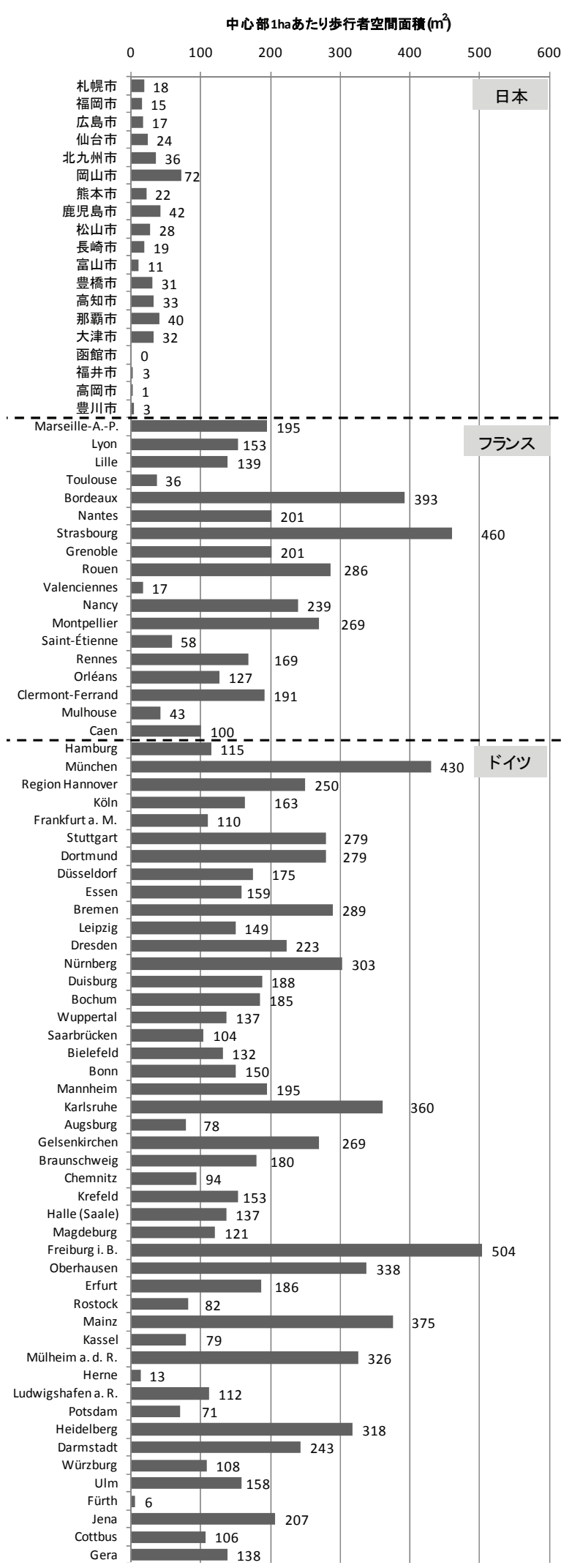

図-9 都市中心部1haあたりの歩行者空間面積

同条件での比較が可能となるよう，対象都市ごとに，都 市中心部の全駅の平均運行頻度と歩行者空間から $100 \mathrm{~m}$ 圈内に立地する鉄軌道駅の平均運行頻度を求めた．図10 に示すように，日本では，札幌市など 5 都市で，歩 

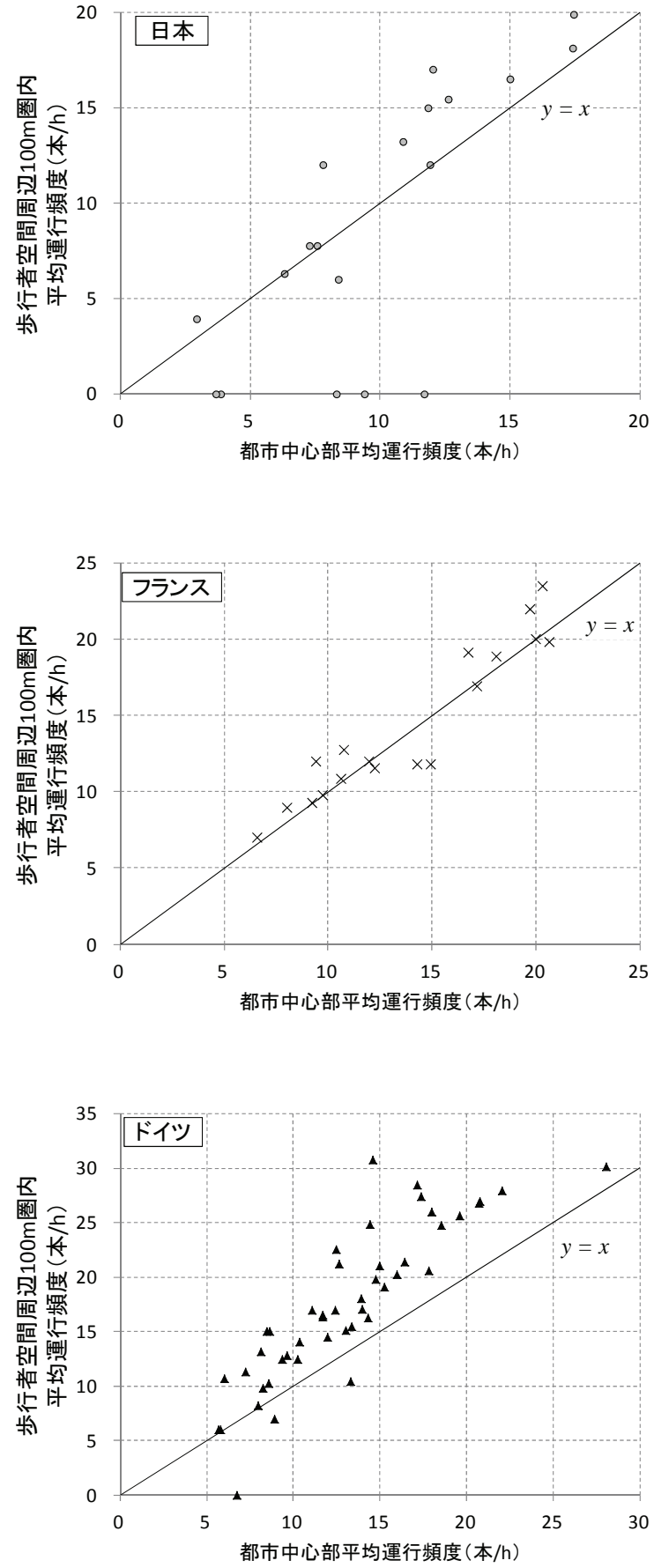

図-10 都市中心部平均運行頻度と歩行者空間周辺平均運行 頻度の関係

行者空間周辺 $100 \mathrm{~m}$ 圈内に鉄軌道駅が存在しないため, 歩行者空間 $100 \mathrm{~m}$ 圈内の鉄軌道駅平均運行頻度が 0.00 と なっている一方，広島，松山，富山などでは，鉄軌道駅 平均運行頻度が都市中心部の鉄軌道駅平均運行頻度を上 回っており，利便性の高い鉄軌道駅と歩行者空間との近 接性に大きな差がみられる.

次に, フランスとドイツの都市を比較すると，歩行者 空間 $100 \mathrm{~m}$ 圈内の鉄軌道駅平均運行頻度が都市中心部の 鉄軌道駅平均運行頻度を上回る都市，すなわちに図-10
おいて, $y=x$ の直線より左上にプロットされている都市 は，フランスでは 18 都市中 9都市，ドイツでは 46都市 中 43 都市となり，その割合に大きな差がみられ，ドイ ツの都市の方がフランスの都市よりも歩行者空間の周辺 の鉄軌道駅の運行頻度が相対的に高くなっており，利便 性の高い鉄軌道駅と歩行者空間との近接性がより高いと いえる.

これは，フランスでは，ほとんどの都市で過去に中心 部の軌道系都市内交通路線（主に路面電車）が全廃され た後，1990 年代以降を中心に新たな路線（主に LRT） が敷設されており，フランスの軌道系都市内交通は路線 系統の数が少なく，さらに，新たに敷設された路線では 既存の歩行者空間とのアクセスを考慮して駅を設置して いると考えられるため，都市中心部の鉄軌道駅平均運行 頻度と歩行者空間 $100 \mathrm{~m}$ 圈内の鉄軌道駅平均運行頻度の 值にほとんど差が生じていないためであると考えられる。

一方ドイツでは，軌道系都市内交通路線の廃止はフラ ンスに比べて少なかったため, 都市中心部においても軌 道系都市内交通の路線網が充実している。 そのため, ド イツの軌道系都市内交通では路線系統の数が多く, 複数 の系統が発着し運行頻度の非常に高い駅が都市中心部に 存在し，さらにそのような駅の周辺に歩行者空間が存在 していることが多いため，歩行者空間 $100 \mathrm{~m}$ 圈内の鉄軌 道駅平均運行頻度が都市中心部の鉄軌道駅平均運行頻度 より約 30\%高く，鉄軌道駅と歩行者空間の近接性が高く なっているものと考えられる.

\section{5. 都市構造指標によるコンパクト性の比較}

\section{（1）鉄軌道駅周辺の人口分布のみを考慮した都市構造 指標によるコンパクト性の比較}

本節では，3.で算出した駅勢圈域人口割合や高密地区 人口割合などの指標を用いて，主成分分析により都市構 造を現す指標を導出し，都市構造のコンパクト性を国際 間比較する.

駅勢圈域人口割合など $6 つ の$ 指標を用いて主成分分析 を行った結果を表-3に示す．第1主成分をみると，寄与 率が 69.7\% 6 60\%を上回り, 全ての指標で主成分負荷量 が正となっており，運行頻度の高い駅と高密地区および 超高密地区の近接性が高い都市の方が第 1 主成分得点は 高くなっている，最も主成分負荷量が大きいのは，便利 な駅の駅勢圈域人口割合, 次いで駅勢圈域人口割合であ り，鉄軌道駅の周辺に人口が集中するほど，コンパクト な都市構造であるといえるため，第 1 主成分を都市構造 指標 A とする.

次に，対象都市を国および軌道系都市内交通の有無に よって6つのグループに分けて，それぞれのグループで 
表-3 主成分分析結果（都市構造指標A）

\begin{tabular}{|c|c|c|c|}
\hline \multicolumn{2}{|r|}{ 変数 } & 第1主成分 & 第2主成分 \\
\hline 主 & 駅勢圏域人口割合 & 0.919 & -0.203 \\
\hline 成 & 便利な駅の駅勢圏域人口割合 & 0.954 & -0.147 \\
\hline 分 & 高密地区人口割合 & 0.566 & 0.791 \\
\hline 負 & 超高密地区人口割合 & 0.768 & 0.197 \\
\hline 荷 & 高密地区に占める便利な駅の駅勢圏域人ロシェア & 0.877 & -0.071 \\
\hline 量 & 超高密地区に占める便利な駅の駅勢圏域人ロシェア & 0.863 & -0.243 \\
\hline \multicolumn{2}{|r|}{ 固有值 } & 4.179 & 0.790 \\
\hline \multicolumn{2}{|r|}{ 寄与率 } & $69.66 \%$ & $13.17 \%$ \\
\hline
\end{tabular}

表-4 都市構造指標Aの平均值の差の検定結果

\begin{tabular}{|c|c|c|c|c|c|c|c|}
\hline P值 & \begin{tabular}{|c|} 
日本, \\
軌道系 \\
都市内交通 \\
あり \\
\end{tabular} & 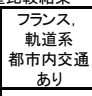 & 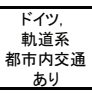 & $\begin{array}{c}\text { 日本, } \\
\text { 軌道系 } \\
\text { 都市内交通 } \\
\text { なし }\end{array}$ & \begin{tabular}{|c|} 
フランス, \\
軌道系 \\
$\begin{array}{c}\text { 都市内交通 } \\
\text { なし }\end{array}$ \\
\end{tabular} & $\begin{array}{c}\text { ドイツ, } \\
\text { 軌道系 } \\
\text { 都市内交通 } \\
\text { なし } \\
\end{array}$ & 平均値 \\
\hline $\begin{array}{c}\text { 日本, 軌道系 } \\
\text { 都市交通あり }\end{array}$ & - & 0.121 & $0.000^{* *}$ & $0.000^{* *}$ & 0.000 ** & 0.156 & 0.532 \\
\hline $\begin{array}{l}\text { フランス，軌道系 } \\
\text { 都市内交通あり }\end{array}$ & - & - & $0.000^{* *}$ & $0.000^{\star *}$ & $0.000^{* *}$ & $0.000^{* *}$ & 1.374 \\
\hline $\begin{array}{c}\text { ピツ, 軌道系 } \\
\text { 都市内内交通亚上 }\end{array}$ & - & - & . & $0.000^{* *}$ & $0.000^{* *}$ & $0.000^{* *}$ & 3.520 \\
\hline $\begin{array}{l}\text { 日本, 謰道系 } \\
\text { 都市内交通な2 }\end{array}$ & - & - & - & - & 0.909 & $0.000^{\star *}$ & -1.318 \\
\hline $\begin{array}{l}\text { フランス, 軌道系 } \\
\text { 都市内通なし }\end{array}$ & - & - & - & - & - & $0.000^{* *}$ & -1.237 \\
\hline $\begin{array}{l}\text { トイツ、軌道系 } \\
\text { 都市内交通なし }\end{array}$ & - & - & - & - & - & - & $\mid-0.130$ \\
\hline
\end{tabular}

の都市構造指標 A の平均值の差を多重比較により検定 する. なお，検定の方法は，以下に示す方法を用いる. まず，Bartlett 検定を用いて等分散性を検定する．等分散 性を棄却できない場合は，Tukey の方法を用いた多重比 較により，平均值の差を検定する。一方，等分散性が充 却された場合は，Steel-Dwass の方法を用いた多重比較に より, 平均值の差を検定する. Steel-Dwass の方法とは, Tukey の方法をノンパラメトリック法で適用したもので ある33)，検定の結果を，表-4に示す.

軌道系都市内交通のある都市のグループ同士を比較す ると，ドイツと日本およびドイツとフランスの間のみ, 都市構造指標 $\mathrm{A}$ に 1\%水準で有意な差がみられる.しか し，日本とフランスの間の都市構造指標 A には有意な 差はみられない. 従って，「鉄軌道駅周辺の人口分布」， 「人口密度の高い地区の分布」の観点のみで都市構造を 比較した場合，ドイツの都市構造は，日本やフランスに 比べてコンパクトであるといえるが，日本とフランスの 間には，都市構造に有意な差があるとはいえない。

\section{（2）歩行者空間の分布を考慮した都市構造指標による コンパクト性の比較}

本節では，4.で算出した歩行者空間周辺の鉄軌道運行 頻度を指標として追加し，鉄軌道駅と歩行者空間の近接 性を考慮した都市構造を現す指標を主成分分析により導 出する. 具体的には，都市構造指標Aで用いた指標から， 高密地区人口割合を除き，歩行者空間周辺 $100 \mathrm{~m}$ 圈内鉄 軌道駅平均運行頻度を加えている.ただし，4.で算出し
表-5 主成分分析結果（都市構造指標B）

\begin{tabular}{|c|c|c|c|}
\hline \multicolumn{2}{|r|}{ 変数 } & \begin{tabular}{|l|} 
第1主成分 \\
\end{tabular} & 第2主成分 \\
\hline 主 & 駅勢圈域人口割合 & 0.921 & -0.098 \\
\hline 成 & 便利な駅の駅勢圈域人口割合 & 0.957 & -0.086 \\
\hline 分 & 超高密地区人口割合 & 0.709 & 0.582 \\
\hline 負 & 高密地区に占める便利な駅の駅勢圏域人ロシェア & 0.875 & 0.038 \\
\hline & 超高密地区に占める便利な駅の駅勢圈域人ロシェア & 0.812 & 0.135 \\
\hline 量 & 歩行者空間周辺鉄軌道駅運行頻度 & 0.710 & -0.538 \\
\hline & 固有值 & 4.195 & 0.665 \\
\hline & 寄与率 & $69.92 \%$ & $11.08 \%$ \\
\hline
\end{tabular}

表-6 都市構造指標Bの平均值の差の検定結果

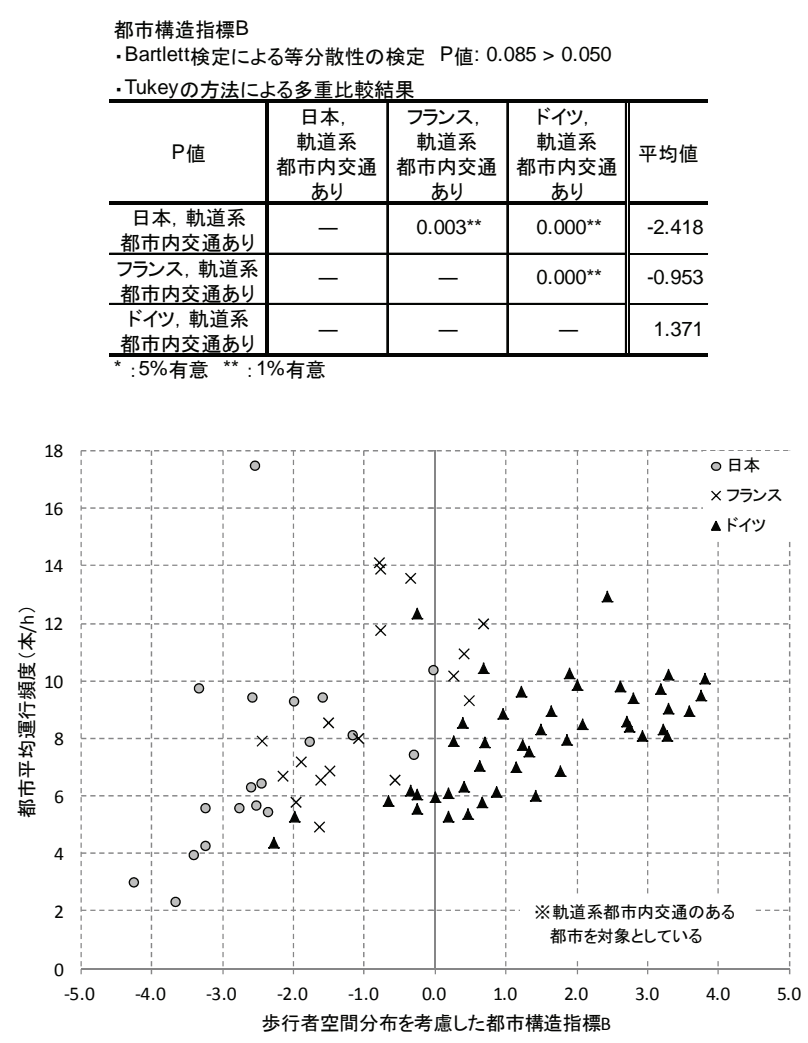

図-11 都市構造指標 B と都市平均運行頻度の関係

た歩行者空間と鉄軌道駅の近接性に関する指標は，軌道 系都市内交通のある都市の久算出しているため, 都市構 造指標Bは軌道系都市内交通のある都市でのみ算出する.

主成分分析の結果を表-5に示す，第 1 主成分をみると， 寄与率が 69.9\% と都市構造指標 Aのそれよりも高くなっ ている. また，全ての指標で主成分負荷量が正となって おり，運行頻度の高い駅と高密地区および超高密地区の 近接性が高い都市の方が第 1 主成分得点は高くなってい る. 歩行者空間 $100 \mathrm{~m}$ 圈内鉄軌道駅運行頻度についても 第 1 主成分 の主成分負荷量は 0.710 と比較的高く, 鉄 軌道駅と歩行者空間との近接性が高い都市ほど第 1 主成 分得点が高くなっている. よって, 第 1 主成分を都市構 造指標 B とする.

次に，国ごとに都市構造指標 $\mathrm{B}$ の平均值の差を，多 
重比較により検定した．なお，検定の方法は，前述の方 法と同様である．検定の結果を，表-6 に示す．また， 日本，フランス，ドイツの軌道系都市内交通が存在する 都市について, 都市構造指標 B と都市内の全鉄軌道駅 の運行頻度を平均した都市平均運行頻度の関係を散布図 で表したものを図-11に示す.

検定の結果，都市構造指標 B は，全てのグループ間 で $1 \%$ 水準で有意な差がみられる. 特に，日本とフラン スの間では，都市構造指標 A では有意な差がみられな かったが，都市構造指標 B においては有意な差がみら れたことより，歩行者空間の分布を考慮した場合，フラ ンスの都市は日本の都市に比べてコンパクトであること を定量的に示すことができたといえる，また，図-11に 示すように, 都市構造指標 B の高い都市にはドイツの 都市が多く, 都市構造指標 B が 1.0 を上回るのはすべて ドイツの都市である.さらに，それぞれの国において都 市間で比較すると, 都市構造指標 B の高い都市ほど都 市平均運行頻度が高くなる傾向がみられ，コンパクトな 都市の形成に対する利便性の高い公共交通の影響力の大 きさを示唆しているものと考えられる.

\section{6. 結論}

本研究では，日本・フランス・ドイツの地方都市にお ける，鉄軌道駅の運行頻度ならびに歩行者空間の分布状 況と都市構造との関連を実証データにより国際間比較し, 都市構造の差異を定量的に分析した.

まず， $500 \mathrm{~m}$ 駅勢圏域内の人口が都市人口に占める割 合を算出した。その結果, 日本 $15.6 \%$, フランス, 18.5\%，ドイツ $43.7 \%$ となり，特に，駅勢圏域人口割合 が 40\%を上回る都市は，日本には 1 都市も存在しないが， フランスでは Grenoble, Montpellierの 2 都市, ドイツでは Karlsruhe の 74.0\%を筆頭に 37 都市存在し，各国間の相違 が顕著に現れる結果となった。

次に，人口密度 40 人/ha 以上の地区の人口に占める便 利な駅（運行頻度が高い駅として，3 本/h 以上の鉄道駅 および 6 本/ $\mathrm{h}$ 以上の軌道駅を合わせたもの）の 500m 駅 勢圈域内の人口のシェアを算出した結果，ドイツ $55.6 \%$, フランス $24.9 \%$, 日本 $15.0 \%$ となり, 逆に, 日本では, 人口密度 40 人/ha 以上の地区の $78.9 \%$ ○人々が鉄軌道 駅から $500 \mathrm{~m}$ 以上離れた場所に居住しており，都市内交 通の利便性が高い地区に必ずしも高密に人々が居住して いるとは限らないことを明らかにした。そして，便利な 駅の $500 \mathrm{~m}$ 駅勢圈域内の人口のシェアを都市別にみると, 日本では 40\%を越える都市は見られなかったが，フラン スでは Nantes など 4 都市，ドイツでは Karlsruhe の 92.2\% を筆頭に 38 都市で 50\%を上回り，特に，ドイツにおい
て人口密度の高い地区と鉄軌道駅の近接性が高いことを 明らかにした。

そして, 都市中心部 1ha あたりの歩行者空間面積を比 較した結果，日本の都市中心部の歩行者空間は，フラン ス，ドイツと比較すると 9 分の 1 程度にとどまっている ことを明らかにした.さらに，歩行者空間 $100 \mathrm{~m}$ 卷内の 鉄軌道駅平均運行頻度と都市中心部の鉄軌道駅平均運行 頻度の関係を分析した結果，日本では歩行者空間 $100 \mathrm{~m}$ 圈内に鉄軌道駅がない都市が札幌市など 5 都市あり，利 便性の高い鉄軌道駅と歩行者空間との近接性に大きな差 がみられた。 また，歩行者空間 $100 \mathrm{~m}$ 圏内の鉄軌道駅平 均運行頻度が都市中心部の鉄軌道駅平均運行頻度より高 い都市がドイツでは 9割以上であるのに対し，フランス では 5 割にとどまっており，都市中心部 1ha あたりの歩 行者空間面積の平均值では大差がない両国であるが, 鉄 軌道駅と歩行者空間との近接性については，ドイツの都 市の方がフランスの都市よりも高いことを明らかにした.

さらに, 総合的な都市構造指標を主成分分析により導 出し, 都市構造のコンパクト性を国際間比較した。その 結果, ドイツの都市構造は, 日本やフランスの都市に比 ベてコンパクトであること，また，日本とフランスの都 市を比較すると, 歩行者空間と鉄軌道駅との近接性の差 を考慮した場合, フランスの都市の方がコンパクトな都 市構造を実現していることを定量的に明らかにした。

以上のように，日本・フランス・ドイツの 3 カ国の全 地方都市を対象として, その都市構造を比較した結果, ドイツの都市では，フランス・日本の都市と比較して， 利便性の高い駅周辺に人口や歩行者空間が集中している ことが明らかになったが，これは，ドイツでは古くから， 特に都市中心部において軌道系都市内ネットワークが密 に構築され，そのネットワークを現在に至るまで維持し ている都市が多いためであると考えられる。一方, フラ ンスや日本では，モータリゼーションの進展に伴い，大 多数の都市において軌道系都市内交通ネットワークを廃 止しており，このことが都市の拡散に拍車をかけたと考 えられる.しかしながら, 近年フランスでは, 再び軌道 系都市内交通ネットワークの構築が急速に進められてお $\eta^{34), 35), 36), 37)}$ ，本研究の分析においても，その成果が現れ る結果となっている.

最後に, 本研究の今後の課題としては, 本研究では主 に地区レベルの人口を用いて都市構造を比較しているが， 人口以外の指標として, 各地区における従業者や商品販 売額などを用いるとともに，当該地区の都市計画上の諸 規制等も踏まえた，より詳細な分析が挙げられる．また， 対象とする都市内交通ネットワークについても, 近年, 特にヨーロッパの都市においては，連接バスや二連接バ スなどが導入されており, 従来のバスと比較して輸送量 が大幅に増加していることから，鉄軌道のみならず，こ 
うした路線バスも含めた分析も必要であると考える.さ らに，現在の都市の構造は，例えば，城郭都市や門前町 といった，それぞれの都市の起源や歴史的経緯などの積 み重なりにより体現されるものであり，また，それぞれ の都市で構築されている都市内交通ネットワークについ ても，その形成過程は大きく異なっており，こうした点 を考慮することも今後の課題の一つである.

\section{参考文献}

1) たとえば，北村隆一：鉄道でまちづくり一豊かな公共 領域がつくる賑わい一, pp.94-96, 学芸出版社, 2004.

2）たとえば，青山吉隆，小谷通泰編：LRT と持続可能な まちづくり, pp.12-22, 学芸出版社, 2008.

3) 谷口守: コンパクトシティ, 交通工学, Vol.37, No.2, pp.27-28, 2002.

4) 古谷知之: 少子高齢化・人口減少局面における市街地 のコンパクト化，交通工学，Vol.37，No.2，pp.29-34, 2002.

5) 谷口 守, 池田大一郎, 中野 敦: 都市コンパクト化 に配慮した住宅地整備ガイドライン構築のための基礎 分析, 土木計画学研究・論文集, Vol.18, No.3, pp.431-438, 2001.

6) 中道久美子, 谷口 守, 松中亮治: 都市コンパクト化 政策に対する簡易な評価システムの実用化に関する研 究一豊田市を対象にした SLIM CITY モデルの応用一, 都市計画論文集，No.39-3，pp.67-72， 2004.

7) Newman, P. and Kenworthy, J.: Cities and automobile dependence, An international sourcebook, Gower Technical, 1989.

8) Glaeser, E. and Kahn, M.: The greenness of cities: carbon dioxide emissions and urban development, NBER Working Paper No. 14238, JEL No. Q5, 2008.

9) 谷口守, 松中亮治, 平野全宏 : 都市構造からみた自 動車 $\mathrm{CO}_{2}$ 排出量の時系列分析, 日本都市計画学会都市 計画論文集，No.43-3，pp.121-126， 2008.

10) 牧野夏樹, 中川 大, 松中亮治, 大庭哲治: コンパク トシティ施策が都市構造・交通環境負荷に及ぼす影響 に関するシミュレーション分析, 都市計画論文集, No.44-3, pp.739-744, 2009.

11) Bagley, M.N. and Mokhtarian, P.: The impact of residential neighborhood type on travel behavior; a structural modeling approach, Annals of Regional Science, No.36, pp.279-297, 2002.

12) 中道久美子, 島岡明生, 谷口 守, 松中亮治 : サステ イナビリティ実現のための自動車依存特性に関する研 究, 日本都市計画学会都市計画論文集, No.40-3, pp.37-42, 2005.

13) 長尾基哉, 中川大，松中亮治，大庭哲治，望月明 彦: 地方都市に㧍ける鉄道・軌道の運行頻度に着目し た駅周辺人口分布の経年变化に関寸る研究, 土木計画 学研究・論文集, Vol.27, No.2, pp.399-407, 2010.

14) Nagao, M., Nakagawa, D., Matsunaka, R., Oba, T. and Mochizuki, A.: How has the distribution of the population in local cities been changing over time according to the frequency of railways and tramways? (Ed. by C.A. Brebbia), Urban Transport XV, Urban Transport and the Environment in the 21st Century, pp.325-336, WIT press, 2009.
15) Hass-Klau, C. and Crampton, G. : Future of Urban Transport -Learning from Success and Weakness: Light Rail-, Environmental and transport planning, 2002.

16) 松中亮治, 谷口 守, 小川千尋：LRT・路面電車の都 市および沿線特性に関する比較分析 ーフランス・日 本を対象として一, 土木計画学研究・講演集, Vol.38 CD-ROM, 2008.

17) 中道久美子, 橋本晋輔, 谷口守, 松中亮治 : LRT 等 の整備状況と居住者の自動車利用の関係に関する研究, 第 27 回交通工学研究発表会論文報告集, pp.241-244, 2007.

18) Hass-Klau, C. : Impact of pedestrianization and traffic calming on retailing -A review of the evidence from Germany and the UK-, Transport Policy, Vol.1, No.1, pp.2131, 1993.

19) 濱名 智, 中川大, 松中亮治, 大庭哲治 : 歩行者空 間の整備状況と商店街の賑わいについての関連分析, 土木計画学研究・論文集, Vol.27, No.2, pp.313-321, 2010.

20) Jefferson, C.: Improving access by public transport, Landscape and Urban Planning, Vol.35, pp.173-179, 1996.

21) 国土数值情報ダウンロードサービス http://nlftp. mlit.go.jp/ksj/index.html（2011 年 1 月 26 日最終閲覧）

22) ESRI : ESRI Data \& Maps -World, Europe, Canada, and Mexico-, 2005. (CD-ROM)

23) Google Map http://maps.google.co.jp/（2011 年 1 月 31 日 最終閲覧)

24) 交通新聞社 : JR 時刻表, 2005.

25) JTB パブリッシング : JTB 私鉄時刻表 東日本版・西 日本版, 2005.

26) HaCon Ing. GmbH : HaCon Fahrplan-Auskunfts-System, 2009.

27）（財）統計情報研究開発センター：平成 17 年国勢調 査 地域メッシュ統計（世界測地系），2007。

28) Insee : Recensement de la population 2006 exploitations principale et complémentaire, 2010.

29) infas geodaten : Geometry of the "Wohnquartiere" incl. population data with age (17 classes) and sex, Area 2008, 2010.

30) 昭文社 : 都市地図シリーズ，2009 2010.

31) IGN PARIS : PLAN DE VILLE, 2004 2007.

32) Falk Verlag : Falk Stadtpläne Extra, 2004 2010.

33) 石村貞夫, 石村光資郎：入門はじめての分散分析と多 重比較, 東京図書, 2008.

34) Document récapitulatif de la table ronde : les 268 engagements du Grenelle, 2007.

35) Summary report on Round Table discussions held at the Hôtel de Roquelaure on 24, 25 and 26 October 2007, 2007.

36) Ministère de l'Ecologie, de l'Energie, du Développement Durable et de l'Aménagement du Territoire : Dossier de presse Grenelle Environnement 1er appel à projets Transports Collectifs en Site Propre (TCSP), 2009.

37) Ministère de l'Ecologie, de l'Energie, du Développement Durable et de l'Aménagement du Territoire : Dossier de presse Grenelle Environnement présentent les lauréats du 2ème appel à projets transports collectifs en site propre (TCSP), 2011.

(2011. 7. 25 受付) 


\section{THE INTERNATIONAL COMPARISON OF URBAN STRUCTURE FOCUSING ON THE SERVICE FREQUENCY OF RAILWAYS AND TRAMWAYS AND ON THE PEDESTRIAN SPACES TARGETING ON LOCAL CITIES}

\section{Ryoji MATSUNAKA, Tetsuharu OBA, Dai NAKAGAWA and Motoya NAGAO}

We compared the relationship of the compactness of urban structure, with the service frequencies of railways and tramways stations, and also with the spatial distribution of pedestrian spaces in the city center, targeting local cities in Japan, France and Germany. First, we showed that many German cities have higher proportions of populations around stations to those of cities in Japan and France. We also determined that the proximity of pedestrian spaces to railway and tramway stations was high in the order of Germany, France and Japan. Then, we compared the compactness of urban structure of local cities using two urban compactness indices, which we calculated by way of principal component analyses. The results show that German cities have more compact urban structure than cities in Japan and France. Moreover, in the case of considering the proximity of pedestrian spaces to railway and tramway stations, French cities have more compact urban structure than Japanese cities. 